Original Article

\title{
An investigation on the chloroplast and nuclear genomes of taxa belong to the subgenus Dracunculus (Bess.) Rydb. of Artemisia L. (Asteraceae) in Turkey
}

\author{
Uma investigação sobre o cloroplasto e os genomas nucleares de táxons pertencentes \\ ao subgênero Dracunculus (Bess.) Rydb. de Artemisia L. (Asteraceae) na Turquia
}

\author{
P. YILMAZ SANCAR ${ }^{*}$ (D), C. F. WAHID ${ }^{\mathrm{b}}$ (D) S. CIVELEK ${ }^{\mathrm{a}}$ (D) and M. KURSAT ${ }^{\mathrm{C}}$ (D) \\ aFirat University, Faculty of Sciences, Department of Biology, Elazıg, Turkey \\ ${ }^{\mathrm{b}}$ Garmian University, Colleage of Education, Department of Biology, Kalar, Sulaimani, Irak \\ 'Bitlis Eren University, Faculty of Arts and Sciences, Department of Biology, Bitlis, Turkey
}

\begin{abstract}
Artemisia is one of the biggest genera in the family Asteraceae, with around 500-600 taxa at specific and subspecific levels and organised in 5 subgenera. Due to the high number of taxa, a lot taxonomists are trying to solve the problem of its classification and phylogeny but its natural classification still hasn't been achieved. In this research, 60 individuals belonging to 4 taxa of the subgenus Dracunculus of Artemisia L. in Turkey were examined. For all the examined individuals from both the same and different populations belonging to the taxa of the subgenus Dracunculus, the sequences of the regions both $p s b A-t r n \mathrm{H}$ of chloroplast DNA and ITS of nuclear DNA were determined. Also, the gene regions obtained were recorded in the NCBI GenBank database and an accession number was taken. It was found that there was no gene flow and hybridization between the four studied taxa of the subgenus Dracunculus, and these 4 taxa also completed their speciation. According to the results of this molecular study, A. campestris var. campestris, A. campestris var. marschalliana and A. campestris var. araratica were proposed to be raised from the variety level to the species level. This research is important as it is the first molecular based study relating with the subgenus Dracunculus growing in Turkey.
\end{abstract}

Keywords: Artemisia, Phylogeny, cpDNA psbA-trnH, r-DNA ITS, Turkey.

\begin{abstract}
Resumo
Artemisia é um dos maiores gêneros da família Asteraceae, com cerca de 500 a 600 táxons em níveis específicos e subespecíficos e organizados em cinco subgêneros. Em razão do grande número de táxons, muitos taxonomistas estão tentando resolver o problema de sua classificação e filogenia, mas sua classificação natural ainda não foi alcançada. Nesta pesquisa, 60 indivíduos pertencentes a quatro táxons do subgênero Dracunculus de Artemisia L. na Turquia foram examinados. Para todos os indivíduos examinados de populações iguais e diferentes pertencentes aos táxons do subgênero Dracunculus, foram determinadas as sequências das regiões psbA-trnH do DNA do cloroplasto e ITS do DNA nuclear. Além disso, as regiões gênicas obtidas foram registradas no banco de dados do NCBI GenBanke um número de acesso foi obtido. Foi constatado que não houve fluxo gênico nem hibridização entre os quatro táxons estudados do subgênero Dracunculus, os quais também completaram sua especiação. De acordo com os resultados deste estudo molecular, A. campestris var. campestris, A. campestris var. marschalliana e A. campestris var. araratica foram propostos para ser elevados do nível de variedade para o nível de espécie. Esta pesquisa é importante porque é o primeiro estudo de base molecular relacionado com o subgênero Dracunculus em crescimento na Turquia.
\end{abstract}

Palavras-chave: Artemisia, Filogenia, cpDNA psbA-trnH, r-DNA ITS, Turquia.

\section{Introduction}

Artemisia L. is one of the larger genera in the family Asteraceae and the largest genus in the tribe Anthemideae, and comprises of 200 to more than 500 taxa at the specific or subspecific level (McArthur, 1979; Mabberley, 1987; Ling, 1991a; Ling, 1991b; Bremer and Humphries, 1993; Ling, 1995a; Ling, 1995b; Torrell et al., 1999).
The genus Artemisia L. contains all life forms except trees: Annual, biennial and perennial herbs, suffruticoses (subshrubs), fruticose (shrubs), with some large in stature.

The genus Artemisia in the Flora of Turkey are not divided to sections or subgenera. At the same time, none of the species have infraspecific taxa. 
There are total of 23 species without any infraspecific taxa that belong to the genus Artemisia in the $5^{\text {th }}$ and $10^{\text {th }}$ volumes of the Flora of Turkey. The species A. campestris L., A. marschalliana Sprengel, A. araratica Krasch and A. scoparia Waldst. \& Kit. are four of 23 independent species (Davis, 1975; Davis et al., 1988). In fact, these four species belong to the subgenus Dracunculus, but the genus Artemisia in the Flora of Turkey did not divide into subgenera.

Civelek et al. (2010) carried out a revisionary study of the genus Artemisia in Turkey. According to results of this revisionary study, there are 3 subgenera, 22 species, and 26 taxa, which also include 8 infraspecific taxa belonging to the genus Artemisia in Turkey (Civelek et al., 2010; Kursat, 2010; Kursat et al., 2011a; Kursat et al., 2011b; Kursat et al., 2014; Kursat et al., 2015; Kursat et al., 2018).

The taxa of genus Artemisia were divided into subgenera during the revisionary study. Subgenera Artemisia Less. Dracunculus (Bess.) Rydb. and Seriphidium (Bess.) Rouy. have taxa in Turkey, but the subgenus Tridentatae (Rydb.) McArthur which is endemic to North America has no taxa in Turkey (Civelek et al., 2010; Kursat, 2010; Guner et al., 2012). During the revisionary study of the genus Artemisia, at the same time, it was also observed that the distribution areas of three closely related independent species A. campestris, A. marschalliana and A. araratica in Flora of Turkey have a sympatric distribution, which are partially mixed together (Civelek et al., 2010; Kursat, 2010).

With their distributions in Turkey and with their morphological features in mind, the three closely related independent species A. campestris, A. marschalliana and A. araratica in Flora of Turkey were reduced to a variety levels and these varieties were linked to the species A. campestris.

The taxonomic positions and combinations of the closely related independent three species A. campestris, A. marschalliana and A. araratica in Flora of Turkey changed in the revisionary study of the genus Artemisia in Turkey are as follows: A. campestris L. var. campestris, A. campestris L. var. marschalliana (Spreng.) Poljak. and A. campestris
L. var. araratica (Novopokr.) Poljak. However, because they were needed for the molecular data, the accuracy of the classification based on the morphological data in the revisionary study could not be guaranteed.

For this reason, the purpose of this study was to evaluate the genetic diversity and taxonomic position of the subgenus Dracunculus species in Turkey using some molecular techniques. In addition, the first molecular data for the rDNA ITS and psbA-trnH gene region from Turkey were submitted to the international NCBI GenBank databases.

\section{Material and Methods}

\subsection{Plant Material}

The plant materials used in this study were samples that were collected and diagnosed in the project named "The taxonomic revision of the genus Artemisia L. (Asteraceae) growing in Turkey" conducted by Murat Kursat and Semsettin Civelek in 2010 (Kursat, 2010). Within the scope of this study, the plants that were gathered during the land survey conducted by M. Kursat and S. Civelek, which were turned into herbarium materials, were used. 60 different individuals belonging to the 4 taxa of the subgenus Dracunculus from 17 different populations in Turkey were used. These plants were kept as herbarium materials in the Herbarium in the Faculty of Sciences at Bitlis Eren University. Depending on the with of the populations belonging to the taxa, between 1 and 3 individuals with the same label information were used for each taxon. Localities and geographic distribution where the investigated taxa were gathered, were given in Table 1 and Figure 1.

\subsection{DNA Isolation}

For the DNA isolation, leaf texture of plants that were gathered during the land survey conducted by us (M.K. and

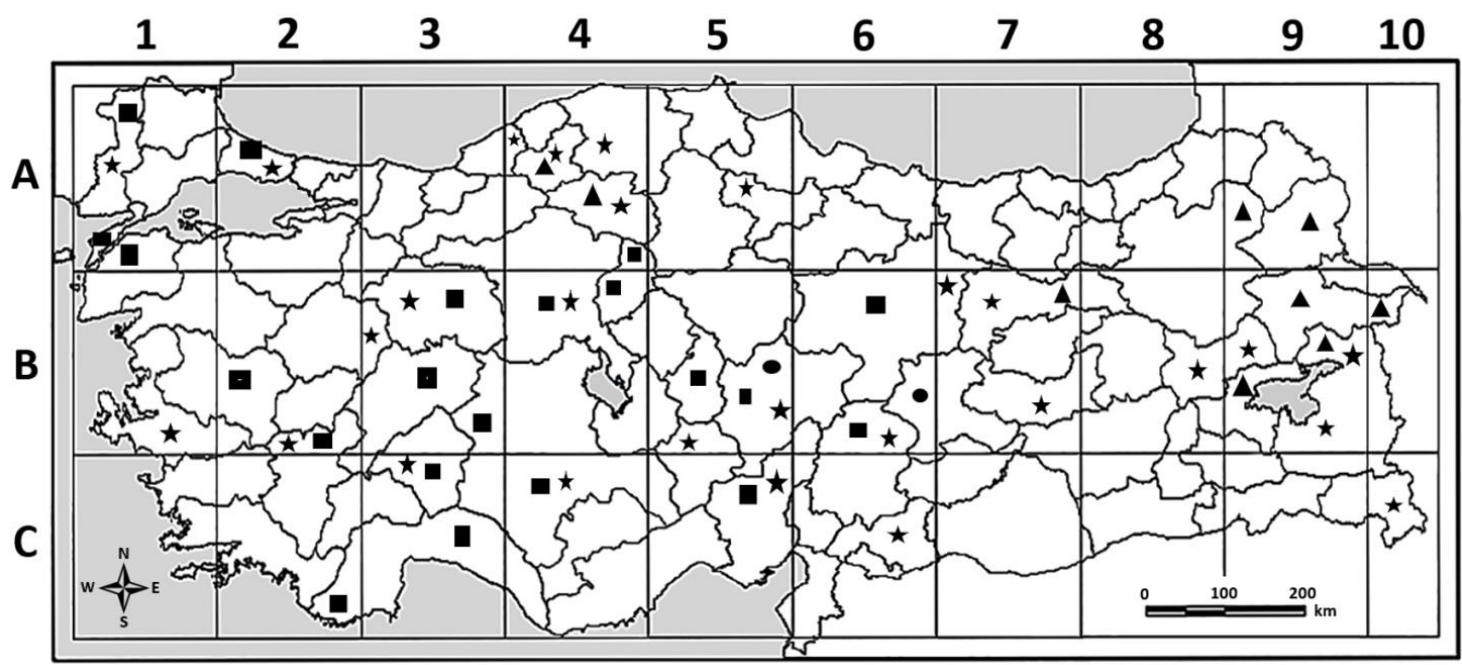

Figure 1. Geographic distribution of four species of the subgenus Dracunculus in Turkey (A. campestris ( $\square$ ), A. marschalliana ( $\mathbf{\Delta})$, A. araratica () and A. scoparia ( $\star$ ) (Civelek et al., 2010, Kursat 2010). 
Table 1. The label information of examined individuals of specimens belong to 4 taxa of the subgenus Dracunculus used in the study.

\begin{tabular}{|c|c|c|c|c|}
\hline $\begin{array}{c}\text { Taxa of The Subgenus } \\
\text { Dracunculus }\end{array}$ & $\begin{array}{l}\text { Number of } \\
\text { specimens }\end{array}$ & Collector & $\begin{array}{l}\text { Collection } \\
\text { date }\end{array}$ & $\begin{array}{l}\text { Detailed localities of } \\
\text { specimens populations }\end{array}$ \\
\hline A. campestris & 1096 & M. Kursat & 10.09.2007 & B4 Ankara: N 39우 43.997, E $32^{\circ} 23.860,843 \mathrm{~m}$ \\
\hline A. campestris & 1015 & S. Civelek and M. Kursat & 01.09 .2007 & $\begin{array}{c}\text { B6 Kahramanmaras: N } 38^{\circ} 12.495, \text { E } 36^{\circ} \\
56.488,1231 \mathrm{~m}\end{array}$ \\
\hline A. campestris & 1017 & M. Kursat & 02.09 .2007 & $\begin{array}{c}\text { B6 Kahramanmaras: N } 37^{\circ} 56.285 \text {, E } 36^{0} \\
34.540,1380 \mathrm{~m}\end{array}$ \\
\hline A. campestris & 1018 & S. Civelek and M. Kursat & 02.09 .2007 & $\begin{array}{c}\text { B6 Kahramanmaras: N } 37^{\circ} 56.285, \text { E } 36^{\circ} \\
34.540,1380 \mathrm{~m}\end{array}$ \\
\hline A. campestris & 1022 & M. Kursat & 05.09 .2007 & C2 Antalya: N 37º 02.114, E 29º 53.304,1430 m \\
\hline A. campestris & 1039 & M. Kursat & 11.09 .2007 & C5 Adana: N 37º 31.449, E 34º 39.159, 1185 m \\
\hline A. marschaliana & 1102 & M. Kursat & 28.10 .2007 & $\begin{array}{c}\text { A4 Çankırı: N 405 50.364, E } 32^{\circ} 42.350 \\
1070 \mathrm{~m}\end{array}$ \\
\hline A. marschaliana & 1176 & M. Kursat & 27.08.2008 & A9 Kars: N 40ํ3․ 38.480 E $43^{\circ} 04.524,2010 \mathrm{~m}$ \\
\hline A. marschaliana & 1046 & S. Civelek and M. Kursat & 19.09.2007 & 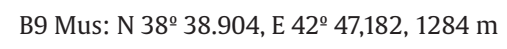 \\
\hline A. marschaliana & 1187 & M. Kursat & 02.11 .2008 & 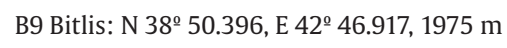 \\
\hline A. marschaliana & 1147 & M. Kursat & 22.06.2008 & 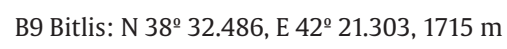 \\
\hline A. marschaliana & 1066 & S. Civelek and M. Kursat & 22.09.2007 & B10 Agri: N 39² 42.618, 1728 m \\
\hline A. marschaliana & 1114 & M. Kursat & 26.11.2007 & B10 Agri: N 39² 35.994, E 42 55.698, 1605 m \\
\hline A. araratica & 1001 & M. Kursat & 04.07 .2007 & B6 Malatya: N 38ํㅜ 11.942, E 37º 50.622, 1495 m \\
\hline A. araratica & 1002 & M. Kursat & 04.07.2007 & 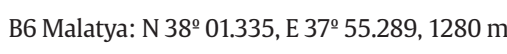 \\
\hline A. scoparia & 1030 & S. Civelek and M. Kursat & 10.09.2007 & B4 Ankara: N 39º 42.876, E $32^{\circ} 17.941,796$ m \\
\hline A. scoparia & 1003 & M. Kursat & 04.07.2007 & $\begin{array}{c}\text { B6 Kahramanmaras: N } 37^{\circ} 56.285 \text {, E } 36^{0} \\
34.540,1380 \mathrm{~m}\end{array}$ \\
\hline A. scoparia & 1189 & M. Kursat & 03.11.2008 & 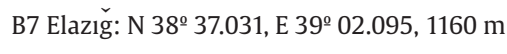 \\
\hline A. scoparia & 1169 & M. Kursat & 26.08 .2008 & B9 Van: $N 38^{\circ} 34.300$, E $43^{\circ} 38.770,1750 \mathrm{~m}$ \\
\hline A. scoparia & 1038 & M. Kursat & 11.09.2007 & C5 Adana: N 37º 31.449, E $34^{\circ}$ 39.159, 1185 m \\
\hline A. scoparia & 1078 & S. Civelek and M. Kursat & 24.09.2007 & 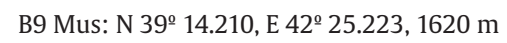 \\
\hline
\end{tabular}

Civelek et al. (2010), Kursat (2010).

S.C.) and which were turned into herbarium materials were used. By modifying the CTAB (Cetyl Trimethyl Ammonium Bromide) method, the DNA isolation was realized manually (Doyle and Doyle, 1987). By measuring the concentrations of the isolated DNAs with a nanodrop spectrophotometer, they were adjusted to $20 \mathrm{ng} / \mathrm{ul}$. The Stock DNA was preserved at $-20{ }^{\circ} \mathrm{C}$.

\subsection{PCR amplification}

In the PCR studies conducted by using psbA - trn $\mathrm{H}$ primers and ITS4-ITS5 primers, psbA-trnH and ITS region for 60 samples was multiplied. The sequence of primers that were used to amplify both $p s b \mathrm{~A}$ - trn $\mathrm{H}$ region and ITS region were given in Table 2 (Taberlet et al., 1991). Aiming to make the final concentration for the PCR studies to be $25 \mu \mathrm{L}$, by mixing $5 \mu \mathrm{L}$ buffer, $1,5 \mu \mathrm{L} \mathrm{MgCl} 2,0,5 \mu \mathrm{L}$ dNTPs, $0,25 \mu \mathrm{L}$ from each primer (forward and reverse), $0,25 \mu \mathrm{L}$ taq polymerase and nearly $6 \mathrm{ng}(1,35 \mu \mathrm{L})$ template of DNA were mixed and the PCR device was repeated for 30 cycles, having $2 \min 95{ }^{\circ} \mathrm{C}$ initial denaturation, 1 min $95{ }^{\circ} \mathrm{C}$ denaturation, $40 \mathrm{~s} 50{ }^{\circ} \mathrm{C}$ (for psbA - trn $\mathrm{H}$ region), and
Table 2. The base sequences of the primers used.

\begin{tabular}{cc}
\hline Primers & Base sequences (5' - 3') \\
\hline ITS5 & 5' GAAAGTAAAAGTCGTAACAAGG 3' \\
ITS4 & 5' TCCTCCGCTTATTGATATGC 3' \\
psbA & 5' GTTATGCATGAACGTAATGCTC 3' \\
trnH & 5' CGCGCATGGTGGATTCACAATCC 3' \\
\hline
\end{tabular}

Taberlet et al. (1991).

$55^{\circ} \mathrm{C}$ (for ITS region) annealing, $1 \mathrm{~min} 72^{\circ} \mathrm{C}$ extension and $5 \mathrm{~min} 72^{\circ} \mathrm{C}$ final extension. PCR products were monitored in agarose gel with a $1 \%$ ratio.

\subsection{Sequence Analysis}

A two-way reading was applied to the amplification products. The PCR purification process was realized before the sequence analysis. The purification and sequencing process was realized by the Macrogen Company. In order to evaluate the data of the chromatograms, a Finch TV 1.4 
version was used. The variable sites, number of parsimony informative sites, genetic distance, nucleotide diversity, and divergence within the species were computed as molecular diversity statistics for each dataset using Molecular Evolutionary Genetics Analysis software (MEGA X) (Kumar et al., 2019). The DNA sequence alignments of the 60 individuals were evaluated by using the $\mathrm{X}$ version of the
MEGA program. The DNA sequence alignments of all the individuals was subject to the statistical analysis within the scope of this program. Ultimately, the phylogenetic trees were constructed by using the Maximum Likelihood Method with 1000 bootstrap replicates. The GenBank accession numbers, where the investigated taxa were gathered, are given in Table 3.

Table 3. Genbank accession numbers for the r-DNA ITS and psbA-trnH regions of the studied samples.

\begin{tabular}{|c|c|c|}
\hline \multirow{2}{*}{ Specimens } & \multicolumn{2}{|c|}{ GenBank Accesion Numbers } \\
\hline & ITS & psbA-trnH \\
\hline A. campestris & MT161431 & MT637764 \\
\hline A. campestris & MT161432 & MT637765 \\
\hline A. campestris & MT161433 & MT637766 \\
\hline A. campestris & MT161434 & MT637767 \\
\hline A. campestris & MT161435 & MT637768 \\
\hline A. campestris & MT161436 & MT637769 \\
\hline A. campestris & MT161437 & MT637770 \\
\hline A. campestris & MT161438 & MT637771 \\
\hline A. campestris & MT161439 & MT637772 \\
\hline A. campestris & MT161440 & MT637773 \\
\hline A. campestris & MT161441 & MT637774 \\
\hline A. campestris & MT161442 & MT637775 \\
\hline A. campestris & MT161443 & MT637776 \\
\hline A. campestris & MT161444 & MT637777 \\
\hline A. campestris & MT161445 & MT637778 \\
\hline A. campestris & MT161446 & MT637779 \\
\hline A. campestris & MT161447 & MT637780 \\
\hline A. marschalliana & MT161406 & MT637745 \\
\hline A. marschalliana & MT161407 & MT637746 \\
\hline A. marschalliana & MT161408 & MT637747 \\
\hline A. marschalliana & MT161409 & MT637748 \\
\hline A. marschalliana & MT161410 & MT637749 \\
\hline A. marschalliana & MT161411 & MT637750 \\
\hline A. marschalliana & MT161412 & MT637751 \\
\hline A. marschalliana & MT161413 & MT637752 \\
\hline A. marschalliana & MT161414 & MT637753 \\
\hline A. marschalliana & MT161415 & MT637754 \\
\hline A. marschalliana & MT161416 & MT637755 \\
\hline A. marschalliana & MT161417 & MT637756 \\
\hline A. marschalliana & MT161418 & MT637757 \\
\hline A. marschalliana & MT161419 & MT637758 \\
\hline A. marschalliana & MT161420 & MT637759 \\
\hline A. marschalliana & MT161421 & MT637760 \\
\hline A. marschalliana & MT161422 & MT637761 \\
\hline A. marschalliana & MT161423 & MT637762 \\
\hline A. marschalliana & MT161424 & MT637763 \\
\hline
\end{tabular}


Table 3. Continuation.

\begin{tabular}{|c|c|c|}
\hline \multirow{2}{*}{ Specimens } & \multicolumn{2}{|c|}{ GenBank Accesion Numbers } \\
\hline & ITS & psbA-trnH \\
\hline A. araratica & MT161425 & MT648000 \\
\hline A. araratica & MT161426 & MT648001 \\
\hline A. araratica & MT161427 & MT648002 \\
\hline A. araratica & MT161428 & MT648003 \\
\hline A. araratica & MT161429 & MT648004 \\
\hline A. araratica & MT161430 & MT648005 \\
\hline A. scoparia & MT161388 & MT637727 \\
\hline A. scoparia & MT161389 & MT637728 \\
\hline A. scoparia & MT161390 & MT637729 \\
\hline A. scoparia & MT161391 & MT637730 \\
\hline A. scoparia & MT161392 & MT637731 \\
\hline A. scoparia & MT161393 & MT637732 \\
\hline A. scoparia & MT161394 & MT637733 \\
\hline A. scoparia & MT161395 & MT637734 \\
\hline A. scoparia & MT161396 & MT637735 \\
\hline A. scoparia & MT161397 & MT637736 \\
\hline A. scoparia & MT161398 & MT637737 \\
\hline A. scoparia & MT161399 & MT637738 \\
\hline A. scoparia & MT161400 & MT637739 \\
\hline A. scoparia & MT161401 & MT637740 \\
\hline A. scoparia & MT161402 & MT637741 \\
\hline A. scoparia & MT161403 & MT637742 \\
\hline A. scoparia & MT161404 & MT637743 \\
\hline A. scoparia & MT161405 & MT637744 \\
\hline
\end{tabular}

\section{Results}

In this research, 60 individuals of 21 specimens taken from 17 different populations belong to 4 taxa of the subgenus Dracunculus were examined. In all the examined individuals from the same and different populations belonging to taxa of the subgenus Dracunculus, were used to determine the sequences of regions both psbA-trn $\mathrm{H}$ of the chloroplast DNA and ITS of the nuclear DNA (ITS1-5.8 gene - ITS2). The peak results of the bi-directional sequences sent to us from Macrogen were evaluated using the Version 1 of the Finch TV program. Using the "Multiple Alignment Blast System" of the automatic sequencing systems, the sequences were aligned. The noticeable differences were manually corrected.

As a result of the scans performed in the NCBI (National Center for Biotechnology Information) database, for two taxa of the genus Artemisia, two reference regions were obtained. The reference base sequences of the two individuals belonging to species $A$. campestris (JX051736.1 and JX073894.1) and A. scoparia (KX581818.1 and KX581973.1) were also included in our analysis to demonstrate the accuracy of the study (Hobbs and Baldwin,
2013; Liu et al., 2017). For a more accurate visualization of the results of the alignment, about $50-100$ base from the beginning and the end were not evaluated by us. For this reason, approximately 686 base pairs for the ITS regions and 464 base pairs for the psbA - trn $\mathrm{H}$ regions were used.

In the phylogenetic tree drawing, the DNA sequences of the ITS (ITS1-5.8gene-ITS2) regions in the nuclear genome and the DNA sequences of the psbA-trnH region in the chloroplast genome were co-evaluated using version $\mathrm{X}$ of the Mega program.

The nucleotide composition and other features of the individuals was determined as a result of the statistical analyzes performed by cutting the excess parts at the head and end of the DNA sequences. In both the separate and co-evaluations of the sequences of the psbA-trn $\mathrm{H}$ and ITS regions of the examined individuals, some of the parameters of the molecular diversity such as the conservated regions $(\mathrm{C})$, variation regions $(\mathrm{V})$, parsimony informative regions $(\mathrm{Pi})$, single parts $(\mathrm{S})$, homologous base pairs (ii), transitional base pairs (si), transversional base pairs (sv), and R value ( $\mathrm{si} / \mathrm{sv}$ ) were calculated and the values obtained were given in Table 4 . 
Table 4. PCR amplified region length and summary statistics from the r-DNA (ITS) and the cpDNA (psbA-trnH) dataset of subgenus Dracunculus.

\begin{tabular}{lccc}
\hline Parameters of Molecular Diversity & ITS region & psbA-trnH region & $\begin{array}{c}\text { Co-evaluated of ITS and } \\
\text { psbA-trnH }\end{array}$ \\
\hline Total individuals & 60 & 60 & 60 \\
Total band Length & 686 & 464 & 1150 \\
The ratio of G-C base pair (\%) & 55 & 28 & 44.3 \\
Conserved regions (C) & 594 & 415 & 1009 \\
Variation regions (V) & 95 & 49 & 144 \\
Single parts (S) & 85 & 33 & 119 \\
Parsimony informative regions (Pi) & 10 & 16 & 25 \\
Homologous base pairs (ii) & 675 & 446 & 1122 \\
Transitional base pairs (si) & 3.00 & 1.00 & 4.00 \\
Transversional base pairs (sv) & 3.00 & 5.00 & 7.00 \\
R value (si/sv) & 1.2 & 0.2 & 0.5 \\
\hline
\end{tabular}

Using the Best DNA / Protein step in the Models menu of this program, the methods that best expressed the phylogenetic relationship between the individuals were determined. In the list of the methods given, the lowest value of the BIC (Bayesian Information Criterion) was found in the $\mathrm{T} 92$ + G (Tamura-3-parameter) method.

The Maximum Likelihood, Neighbor-Joining, UPGMA, and Maximum Parsimony methods were applied separately, but it was decided that the method that best illustrated the evolutionary and phylogenetic relationship between the examined individuals, we worked with, is the Maximum Likelihood method. In the phylogenetic tree drawing, the DNA sequences of the regions both the ITS in the nuclear genome and psbA-trn $\mathrm{H}$ in the chloroplast genome were co-evaluated by using version $\mathrm{X}$ of the Mega program.

Many of the phylogenetic trees were drawn by trying out many methods, and the most useful tree was chosen. In the Maximum Likelihood method, by entering the bootstrap value 100 , a single phylogenetic tree for total of 63 individuals, 60 of which were examined, 2 of which were the control group, and 1 of which was an external group was obtained (see Figure 2 ). The species $A$. campestris and $A$. scoparia as control group, and the species Anthemis cotula L. as an external group were used (Sancar, 2017; Kursat et al., 2018; Sancar et al., 2019).

\section{Discussion}

In this study a phylogenetic systematic study was conducted by using the molecular data of subgenus Dracunculus that grow in Turkey. 60 individuals of 21 specimens taken from 17 different populations belonging to 4 taxa of the subgenus Dracunculus were examined by analyzing the base slice of the regions being obtained, in an attempt to find some information about the closeness and distance of the taxa with each other. This research is important as it is the first molecular based study relating to subgenus Dracunculus growing naturally in Turkey.
In different parts of the world, various research has been carried out to better understand the systematic position of the genus Artemisia and relationships among its (four) subgenera. The phylogenetic relationship among the different Artemisia species collected from different regions of Pakistan based on the chloroplast gene RPS11 was investigated by Mahmood et al. (2011). The molecular phylogenetic analyses of the Hawaiian Artemisia and its worldwide divergence based on nuclear and chloroplast DNA markers were reported by Hobbs and Baldwin (2013). As discussed by Haghighi et al. (2014), the phylogenetic relationships among Artemisia species based on nuclear ITS and chloroplast psbA-trnH DNA markers using three sections of Artemisia, Dracunculus and Serphidium propose that the r-DNA ITS and cpDNA psbA-trn H markers are practicable in the systematic revision of troubled taxa at the intra-genus level in plants. Furthermore, Pellicer et al. (2014) performed phylogenetic analysis of the annual Artemisia within its major lineages and suggested that annual Artemisia have been specially misidentified at a subgeneric level and verified that they are phylogenetically restricted to basal grades. However, to date, very few Artemisia species have been verified with molecular phylogenetic studies based on the nucleotide sequence data in Turkey (Koloren et al., 2016).

Civelek et al. (2010) carried out a revisionary study of the genus Artemisia in Turkey. According to the results of the revisionary study based on the morphological features, there are two species and four taxa belonging to the subgenus Dracunculus in Turkey. These species in the subgenus Dracunculus in Turkey were determined as A. scoparia, A. campestris var. campestris, A. campestris var. marschalliana, A. campestris var. araratica (Civelek et al., 2010; Kursat, 2010).

During the revisionary study of the genus Artemisia in Turkey, it was observed that the closely related independent three species A. campestris, $A$. marschalliana and $A$. araratica in the Flora of Turkey are quite approximate to one another in terms of morphological characters (Civelek et al., 2010; 


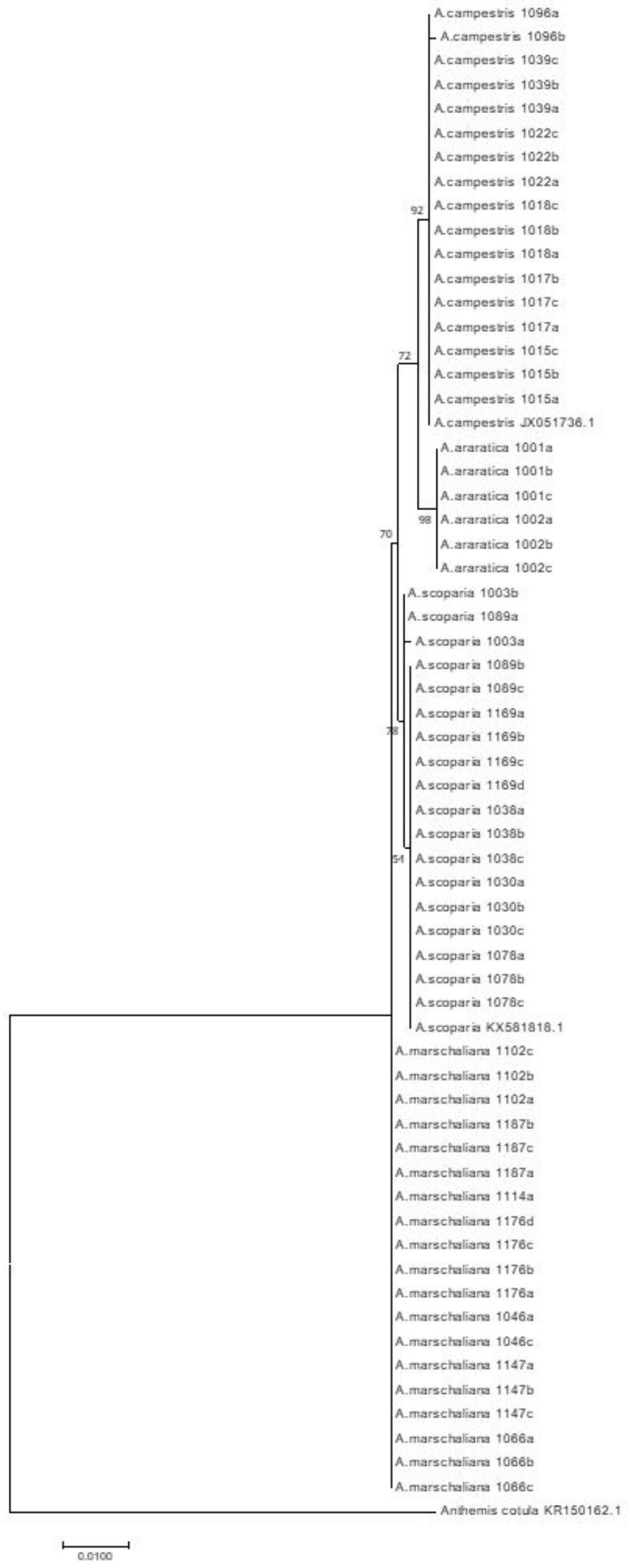

Figure 2. Maximum Likelyhood tree showing the phylogenetic relationship between individuals. 
Kursat, 2010). On the other hand, the two taxa A. scoparia and $A$. campestris var. campestris in the Flora of Turkey are also similar to each other morphologically.

As a result, the taxonomic positions and combinations of the closely related independent three species $A$. campestris, A. marschalliana and A. araratica in the Flora of Turkey changed in the revisionary study of the genus Artemisia in Turkey as follows: A. campestris var. campestris, A. campestris var. marschalliana and $A$. campestris var. araratica. Thus, it has been adapted to their taxonomical positions in the Russian Flora (Davis, 1975; Schinskin and Bobrov, 1995; Civelek et al., 2010; Kursat, 2010; Kursat et al., 2015). However, because they were needed for the molecular data, the accuracy of the classification based on the morphological data in the revisionary study could not be guaranteed. Therefore, this research was planned.

When we look at the phylogenetic tree carefully, it is seen that the phylogenetic tree is divided into two branches in the first stage. One of these branches carries only individuals of the species A. scoparia, while the other carries individuals of varieties belonging to the species A. campestris (see Figure 2). This situation shows that the species $A$. scoparia is an independent apart from the three varieties of the species $A$. campestris and is genetically differentiated from them.

The species A. scoparia is diploid in terms of the chromosome number, and varieties of the species of A. campestris are tetraploid (Civelek et al., 2010; Kursat, 2010). At the same time, the species A. scoparia and varieties of the species of $A$. campestris have different basic chromosome numbers (dysploidy) as $X=8$ and $X=9$ respectively. Genetically, no reproduction can occur between the species $A$. scoparia and varieties of the species A. campestris (Civelek et al., 2010; Kursat, 2010).

The second important finding is that the individuals of species both $A$. campestris and A. scoparia which are used as control groups are found together with the examined individuals of their own species, and makes the reliability of our study $100 \%$ (see Figure 2 ).

It is a third important issue that the individuals of the four taxa belonging to the subgenus Dracunculus are included only in the same branches with their own taxon individuals and do not interfere with individuals belonging to other taxa. This situation is also an indication that there is reproductive isolation among the four taxa, and there is no gene flow and hybridization between them.

It is very interesting that the individuals belonging to each variety of the species $A$. campestris do not interfere with the individuals belonging to the other two varieties of the species A. campestris and are only found together with their own individuals varieties. The following results can be deduced from this situation:

(i). Three varieties of the species A. campestris are very similar morphologically (Civelek et al., 2010; Kursat, 2010). However, these similarities are not dependent on the flow of genes between them because the grouping of the individuals of each taxon only among themselves showed that there is no gene flow between these taxa. In other words, the fact that a complete reproductive isolation between the tetraploid three varieties of the species A. campestris, which have the same basic chromosome numbers, was found.

(ii). The tetraploid three varieties of the species A. campestris may claim that they have separately completed their speciations due to reproductive isolation. However, each variety is not sufficiently differentiated due to the apomictic reproduction in itself. Because a high percentage of the genus Artemisia species are polyploid, numerous apospory and diplospory apomictics were reported for the genus Artemisia (Gustaffson, 1946; Battaglia, 1951; Davis, 1967; Pullaiah, 1984; Czapik, 1996; Carman, 1997; Noyes and Rieseberg, 2000).

The of the classification of the taxa belonging to the subgenus Dracunculus based on the morphological characteristics during the revisionary study of the genus Artemisia in Turkey was tested, and the most accurate classification of these taxa was determined. The fact that the subgenus Dracunculus has four independent species in Turkey was found in this study.

According to the results of this molecular study, A. campestris var. campestris, A.campestris var. marschalliana and A.campestris var. araratica were proposed to be raised from a variety level to species level. Thus, like in the Flora of Turkey, the new systematic positions and combinations of the three varieties of the species $A$. campestris will be independent species A. campestris, A. marschalliana and A. araratica, like the Flora of Turkey (Davis, 1975). Another basis for this new combination is the fact that the individual of the independent species $A$. campestris used as one of the control groups was aggregated side by side on the same branch of phylogenetic tree with the individuals of $A$. campestris var. campestris. A. campestris, A. marschalliana and $A$. araratica species are morphologically similar, but they are different genetically, it means that these species are sibling species.

As a result of this research, original data was obtained for use in new scientific molecular studies on the taxa of genus Artemisia, and provided the haplotypes of $p s b \mathrm{~A}-t r n \mathrm{H}$ and ITS regions for the subgenus Dracunculus taxa in Turkey for the first time in the GenBank database.

\section{Acknowledgements}

This work was supported by the Firat University Scientific Research Projects Coordination Unit [grant number: FF.17.28]. The funding bodies had no role in study design, analysis, decision to publish, or preparation of the manuscript.

\section{References}

BATTAGLIA, E., 1951. Development of angiosperm embryo sac with non - haploid egg. American Journal of Botany, vol. 38, no. 9, pp. 718-724. http://dx.doi.org/10.1002/j.1537-2197.1951.tb14883.x.

BREMER, K. and HUMPHRIES, C.J., 1993. Generic monograph of the Asteraceae-Anthemideae. Bulletin of the British Museum. Natural History Botany, vol. 23, no. 2, pp. 71-177. 
CARMAN, J.G., 1997. Asynchronous expression of duplicate genes in angiosperms may cause apomixis, bispory, tetra spore, and polyembryony. Biological Journal of the Linnean Society, vol. 61, pp. 51-94.

CIVELEK, S., YILMAZ, O., BAGCI, E., KIRBAG, S., GUR, N., TURKOGLU, I., TABUR, S., KURSAT, M., 2010. The researches of taxonomical, chemical (Flavonoids and Essential oils), karyological, palynological and antimicrobial activities on taxa of the genus Artemisia $L$. (Asteraceae) growing in Turkey. TUBITAK . Research project of TUBITAK, TBAG-106T559.

CZAPIK, R., 1996. Problems of apomictic reproduction in the families Compositae and Rosaceae. Folia Geobotanica et Phytotaxonomica, vol.31, no. 3, pp.381-387. http://dx.doi.org/10.1007/BF02815382.

DAVIS, G.L., 1967. Apomixis in the Compositae. Phytomorphology, vol. 17, pp. 270-277.

DAVIS, P.H., 1975. Flora of Turkey and the East Aegean Islands. Edinburgh: Edinburgh University Press. Vol. 5, pp. 311-324.

DAVIS, P.H., MILL, R.R. and TAN, K., 1988. Flora of Turkey and the East Aegean Islands. Edinburgh: Edinburgh University Press. Vol. 10, pp. 163-164.

DOYLE, J.J. and DOYLE, J.L., 1987. A Rapid DNA isolation procedure for small quantities of fresh leaf tissue. Phytochemical Bulletin, vol. 19, pp. 11-15.

GUNER, A., ASLAN, S., EKIM, T, VURAL, M. and BABAC, M.T., 2012. Turkiye Damarli Bitkiler Listesi. Istanbul: Nezahat Gökyigit Botanik Bahcesi ve Flora Aras̨tirmalari Dernegi Yayini, pp. 118-120.

GUSTAFFSON, A., 1946. Apomixis in higher plants. Lunds Universities Arsskrifft, vol. 42-43, pp. 1-370.

HAGHIGHI, A.R., BELDUZ, A.O., VAHED, M.M., COSKUNCELEBI, K. and TERZIOGLU, S., 2014. Phylogenetic relationships among Artemisia species based on nuclear ITS and chloroplast psbAtrnH DNA markers. Biologia, vol. 69, no. 7, pp. 834839. http:// dx.doi.org/10.2478/s11756-014-0379-3.

HOBBS, C.R. and BALDWIN, B.G., 2013. Asian origin and upslope migration of Hawaiian Artemisia (Compositae=Anthemideae). Journal of Biogeography, vol. 40, no. 3, pp. 442454. http://dx.doi. org/10.1111/jbi.12046.

KOLOREN, O., KOLOREN, Z. and EKER, S., 2016. Molecular phylogeny of Artemisia species based on the internal transcribed spacer (ITS) of 18S-26S rDNA in Ordu Province of Turkey. Biotechnology, Biotechnological Equipment, vol. 30, no. 5, pp. 929-934. http:// dx.doi.org/10.1080/13102818.2016.1188674.

KUMAR, S., STECHER, G., LI, M., KNYAZ, C. and TAMURA, K., 2019. MEGA $\mathrm{X}$ : Molecular evolutionary genetics analysis across computing platforms. Molecular Biology and Evolution, vol. 30, pp. 27252729. http://dx.doi.org/10.1093/molbev/msy096. PMid:29722887.

KURSAT, M., 2010. The taxonomic revision of the genus Artemisia $L$. (Asteraceae) growing in Turkey. ElazığTurkey: Institute of Science and Technology of Firat University Biology Department. PhD thesis.

KURSAT, M., CIVELEK, S., SANCAR, Y.P. and TURKOGLU, I., 2018. Artemisia taurica Willd. var. vanensis Kursat \& Civelek (Asteraceae: Anthemideae), a new variety from Eastern Anatolia of Turkey. Biological Diversity and Conservation., vol. 11, no. 3, pp. 106-114.

KURSAT, M., CIVELEK, S., TURKOGLU, I. and TABUR, S., 2011a. Artemisia sieberi Bess. subsp. sieberi A new record for Turkey and a delete record for Turkey Artemisia herba-alba Asso. (Asteraceae). Pakistan Journal of Botany, vol. 43, pp. 18191821.

KURSAT, M., CIVELEK, S., TURKOGLU, I., TABUR, S. and GÜR, N., 2015. A new species of the subgenus Seriphidium of the genus Artemisia L. (Asteraceae) from Turkey. Turkish Journal of Botany, vol. 39, pp. 88-95. http://dx.doi.org/10.3906/bot-1311-33.

KURSAT, M., SANCAR, P.Y. and CIVELEK, S., 2014. New record for the flora of Turkey, Artemisia fragrans Willd. (Asteraceae). OT Sistematik Botanik Dergisi, vol. 21, no. 2, pp. 49-58.
KURSAT, M., TURKOGLU, I., CIVELEK, S. and TABUR, S., 2011b. A new subspecies records for the flora of Turkey: Artemisia santonicum L. subsp. patens. Neilr. K.M. Perss. (Asteraceae). Turkish Journal of Botany, vol. 351, pp. 89. http://dx.doi.org/10.3906/bot-1003-53.

LING, Y.R., 1991a. The Old World Seriphidium (Compositae). Bulletin of Botanical Research, vol. 11, no. 4, pp. 1-40.

LING, Y.R., 1991b. The Old World Artemisia (Compositae). Bulletin of Botanical Research, vol. 12, no. 1, pp. 1-108.

LING, Y.R., 1995a. The New World Artemisia L. In: D.J.N. HIND, C. JEFFREY, G.V. POPE, eds. Advances in Compositae Systematics. Kew: Royal Botanic Gardens, pp. 255-237.

LING, Y.R. 1995b. The New World Seriphidium (Bess.) Four. In: D. HIND, H. BEENTJE, eds. Proceedings of the Kew International Compositae Conference. Kew: Royal Botanic Gardens, vol. I, pp. 283-291.

LIU, G., NING, H., AYIDAERHAN, N. and AISA, H.A., 2017. Evaluation of DNA barcode candidates for the discrimination of Artemisia L. Mitochondrial DNA. Part A, DNA Mapping, Sequencing, and Analysis, vol. 28, no. 6, pp. 956-964. http://dx.doi.org/10.1080 |24701394.2016.1219729. PMid:27607516.

MABBERLEY, D.J., 1987. The Plant Book A portable dictionary of the higher plants. Cambridge: Cambridge University Press.

MAHMOOD, T., HASSAN, N., NAZAR, N. and NAVEED, I., 2011. Phylogenetic analysis of different Artemisia species based on chloroplast gene rps11. Archives of Biological Sciences, vol. 63, no. 3, pp. 661-665. http://dx.doi.org/10.2298/ABS1103661M.

MCARTHUR, E.D., 1979. Sagebrush systematics and evolution. In: UTAH STATE UNIVERSITY. NATURAL RESOURCES ALUMNI ASSOCIATION. Sagebrush Ecosystem Symposium. Logan: Utah State University, pp. 14-22.

NOYES, R.D. and RIESEBERG, L.H., 2000. Two independent loci control agamospermy (Apomixis) in the triploid flowering plant Erigeron annuus. Genetics, vol. 155, no. 1, pp. 379-390. PMid:10790411.

PELLICER, J., HIDALGO, O., GARNATJE, T., KONDO, K. and VALLÈS, J., 2014. Life cycle versus systematic placement: phylogenetic and cytogenetic studies in annual Artemisia (Asteraceae, Anthemideae). Turkish Journal of Botany, vol. 38, pp. 18. http:// dx.doi.org/10.3906/bot-1404-102.

PULLAIAH, T., 1984. Embryology of Compositae. International Bioscience Series, vol. 13, pp. 1-192.

SANCAR, P.Y., 2017. The investigation on the genetic structures and phylogenetic relationships of the species of the genus Anthriscus Pers. (Apiaceae) distribution in Turkey, by use of non - coding "trn" regions of chloroplast genome. Elazığ, Turkey: Institute of Science and Technology, Firat University Biology Department. PhD thesis.

SANCAR, P.Y., CIVELEK, S., TEKIN, M. and DASTAN, S.D., 2019. Investigation of the genetic structures and phylogenetic relationships for the species of the genus Anthriscus pers. (Apiaceae) distributed in Turkey, using the non - codıng "trn" regions of the chloroplast genome. Pakistan Journal of Botany, vol. 51, no. 3, pp. 1049-1057. http://dx.doi.org/10.30848/ PJB2019-3(37).

SCHINSKIN, B.K., BOBROV, E.G., 1995. Flora of the USSR. Israel Program for Scientific Translations. Vol. 26, pp. 404-600.

TABERLET, P., GIELLY, L., PAUTOU, G. and BOUVET, J., 1991. Universal primers amplification of three non-coding regions of chloroplast DNA. Plant Molecular Biology, vol. 17, no. 5, pp. 1105-1109. http:// dx.doi.org/10.1007/BF00037152. PMid:1932684.

TORRELL, M., GARCIA-JACAS, N., SUSANNA, A. and VALLÈS, J., 1999. Phylogeny in Artemisia (Asteraceae, Anthemideae) inferred from nuclear ribosomal DNA ITS sequences. Taxon, vol. 48, no. 4, pp. 721-736. http://dx.doi.org/10.2307/1223643. 